Гавриш О. А.

доктор техн. наук, професор

Чайковський С. О.,

Національний технічний університет України «КПI»

\title{
УКРАЇНСЬКІ МЕТАЛУРГІЙНІ ПІДПРИЕМСТВА: СУЧАСНІ ТЕНДЕНЦІї ТА МІСЦЕ У СВІТОВОМУ МЕТАЛУРГІЙНОМУ ВИРОБНИЦТВІ
}

\section{УКРАИНСКИЕ МЕТАЛЛУРГИЧЕСКИЕ ПРЕДПРИЯТИЯ: СОВРЕМЕННЫЕ ТЕНДЕНЦИИ И МЕСТО В МИРОВОМ МЕТАЛЛУРГИЧЕСКОМ ПРОИЗВОДСТВЕ}

\author{
UKRAINIAN METALLURGICAL ENTERPRISES: CURRENT TRENDS AND \\ PLACE IN THE GLOBAL METALLURGICAL INDUSTRY
}

Металургійна промисловість займає одне з центральних місцьь в економіці України, вона не тільки забезпечує потреби краӥни в чорних $i$ кольорових металах, а й виступає одним з основних постачальників валюти, реалізуючи продукцію на експорт. За даними асочіаціi World Steel (WSA) протягом останніх п’ятнадияти років Україна входить до переліку найбільших у світі виробників металургійної продукиії. У статті проаналізовано статистичні дані Світової металургійної асоиіації за 2000-2014рр. обсягів виробництва чавуну, «сирої» сталі, злитків, гарячекатаного прокату, труб та арматури найбільшими країнами виробниками. Проведено оцінку динаміки обсягів металургійного виробництвва Украӥни та виявлено основні тенденції, щэо склалися у металургійній галузі. Встановлено, щэо вітчизняна металургія все більше поступається своїми позичіями на світовому металургійному ринку. Оцінка сучасного стану металургійного виробництва дозволила дійти висновку про необхідність розробки та реалізації інноваційних стратегій розвитку вітчизняними металургійними підприємствами.

Ключові слова: металургія, металургійна продукція, обсяги виробництва, ланцюгові та базисні темпи росту.

Металлургическая промышленность занимает одно из иентральных мест в экономике Украины, не только обеспечивая потребности страны в черных и иветных металлах, но и являясь одним из основных поставщиков валюты, реализуя продукцию на экспорт. По даннымм ассоџиащии World Steel (WSA) в течение последних пятнадиати лет Украина входит в перечень крупнейших в мире производителей металлургической продукции. В статье проанализированы статистические данные Мировой ассоциации стали за 20002014 г2. объемов производства чугуна, «сырой» стали, слитков, горячекатаного проката, труб, арматуры крупнейшими странами-производителями. Проведено оценку динамики объемов металлургического производства Украины и выявлены основные тенденции в металлургической отрасли. Установлено, что отечественная металлургия все больше теряет свои позиции на мировом металлургическом рынке. Оценка современного состояния металлургического производства позволила прийти к выводу о необходимости разработки реализачии инновачионных стратегий развития отечественными металлургическими предприятиями.

Ключевые слова: металлургия, металлургическая продукция, объемы производства, цепные и базисные темпы роста.

Metallurgy industry plays one of the central roles in economy of Ukraine. It meets the need of the country not only in ferrous and nonferrous metal, but also acts as one of the main currency 
source, selling products for export. Due to information of the World Steel Association (WSA) during last fifteen years, Ukraine has been included into the list of the world biggest producers of metallurgy product. Article analyses statistic data of the World Steel Association about production of cast iron, crude steel, ingots, hot-rolled metal, tubes and tube fittings by the biggest countryproducers during 2000-2014 years. Author assesses dynamic of volumes of metallurgy production in Ukraine and reveals main tendencies in the steel industry. It is determined that domestic metallurgy is constantly losing its positions on the world metallurgy market. Evaluation of modern metallurgy production state has given ability to make a conclusion about necessity of elaboration and realization of innovative development strategies by national metallurgy enterprises.

Key words: metallurgy, metallurgy production, volumes of production, chain and base rate of growth.

Вступ. Металургія є базовою галуззю української промисловості, яка не тільки забезпечує потреби країни в чорних і кольорових металах, а й виступає одним $з$ основних постачальників валюти, реалізуючи продукцію на експорт. Україні має чи не найкраще становище в світі, щодо територіального розміщення основних ресурсів, які використовуються у чорній металургії. Крім того, за оцінками вітчизняних вчених, Україна володіє майже 16\% загальносвітових запасів залізної руди. Але останні роки Україна все більше поступається своїми позиціями на світовому металургійному ринку. Проблеми функціонування металургійних підприємств розглядались в наукових працях багатьох вітчизняних вчених Амоші О. І., Аптекаря С. С., Большакова В. I., Горошкової Л. А., Макогона Ю. В., Мінаева О. А., Тубольцева Л. Г., Резнікової О. С., Плавшуди К. В., Шеремет Т. Г. та інших $[1 ; 2 ; 3 ; 4]$.

В той же час, посилення світової конкуренції в металургійній галузі потребує додаткового вивчення сучасних тенденцій та оцінки місця України у світовому виробництві металургійної продукції.

Постановка за. Метою дослідження $є$ проведення аналізу динаміки обсягів виробництва підприємств металургійної галузі України, порівняння показників вітчизняних підприємств 3 показниками країн найбільших виробників металургійної продукції.

Методологія. Для досягнення поставленої мети були використані: метод порівняння - для вивчення динаміки обсягів виробництва окремих видів металургійної продукції вітчизняними виробниками, графічний метод для наочного представлення виявлених тенденцій металургійного виробництва у світі, табличний - для представлення результатів розрахунку показників динаміки виробництва металургійної галузі України.

Результати дослідження. Як справедливо відзначається багатьма вітчизняними вченими, українська металургійна промисловість є невід'ємною частиною світової металургії $[1 ; 3 ; 4]$. За даними асоціації World Steel (WSA), протягом останніх п’ятнадцяти років Україна входить до переліку найбільших у світі виробників металургійної продукції [5]. Розглянемо динаміку обсягів виробництва таких видів металургійної продукції, як «сира» сталь, чавун, злитки, гарячекатаний прокат, труби та арматура найбільших виробників світу за 2000-2014 роки, визначимо місце вітчизняної металургї та основні тенденції на металургійному ринку. 
Так, по виробництву «сирої» сталі з 2000 р. по 2011 р. Україна стійко займала 8 позицію. Ситуація змінилась 32012 року, на 8 сходинку піднімається Туреччина, на 9 - Бразилія, а Україна посіла 10 місце (рис.1). Основними конкурентами вітчизняним виробникам «сирої» сталі на початку 2000 років були Індія, Бразилія та Італія, на теперішній час до них приєдналась Туреччина.

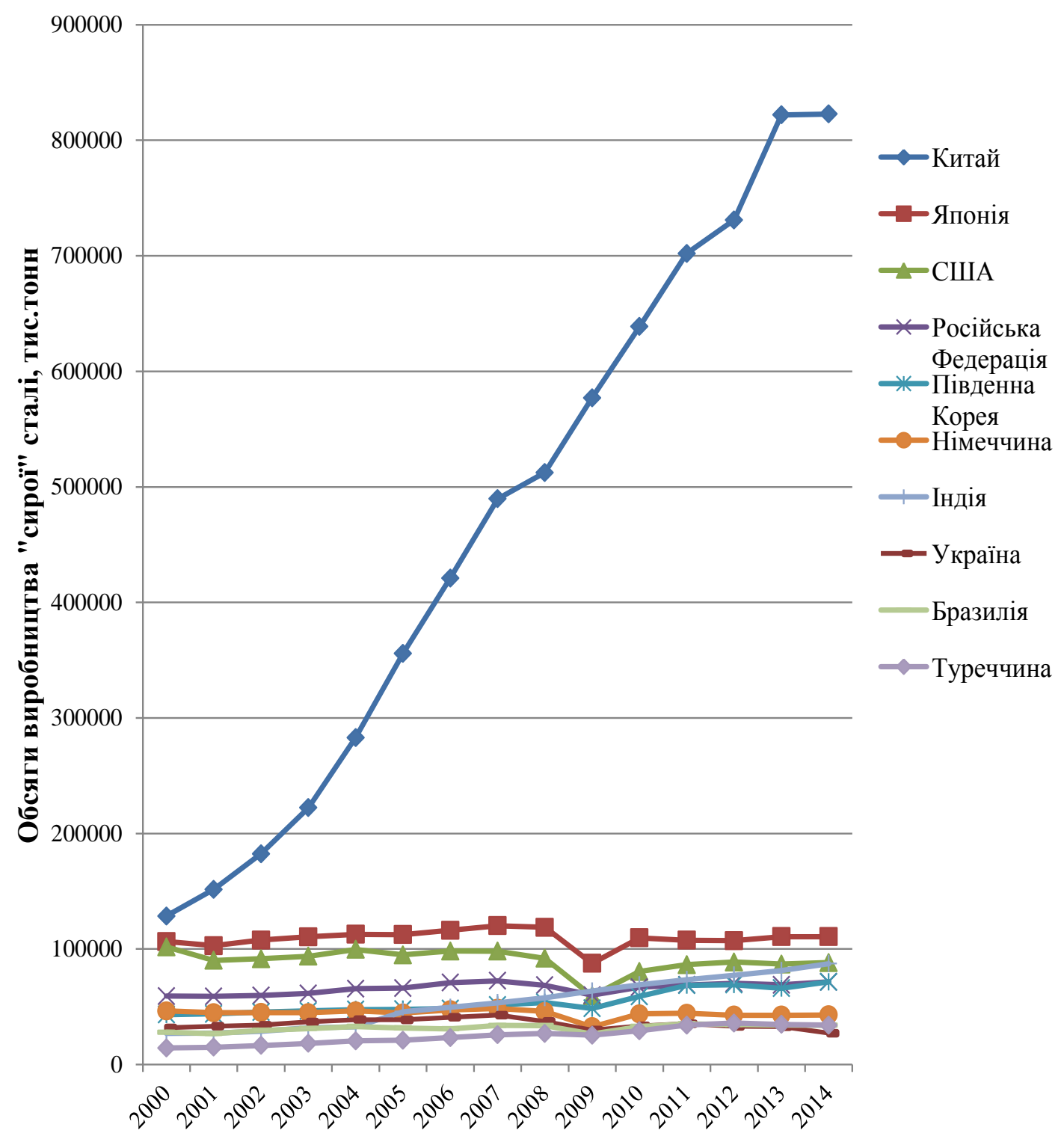

Рис. 1. Діаграма виробництва «сирої» сталі найбільшими країнами виробниками у 2000-2014рp. (побудовано авторами за статистичними даними асоиiauiï World Steel) [5]

Якщо розглянути базисні темпи росту обсягів виробництва «сирої» сталі, то можна відзначити, що в порівнянні з 2000 роком, падіння спостерігалось в 2009 році й склало $6 \%$, і найбільше в 2014 році - 14,5\% (табл. 1). Значний приріст обсягів виробництва «сирої» сталі в порівнянні 32000 роком 
простежується в період з 2004 року по 2007 рік: 2004p. - 21,9\%, 2005p. - 21,6\%, 2006 p. $-28,7 \%, 2007$ p. - 34,8\%. Ланцюгові темпи виробництва «сирої» сталі свідчать про негативну тенденцію падіння обсягів з 2008 року (табл. 2.). Так, в 2008 році в порівнянні з 2007 р. виробництво «сирої» сталі впало на 13\%, у 2009 році в порівнянні з 2008 р. на 19,9\%, у 2012 році в порівнянні з 2011 р. на $6,7 \%$, у 2013 в порівнянні з 2012 р. на 0,6\%, й в 2014 році в порівнянні з 2013 р. на $17,1 \%$.

Щодо виробництва злитків, то за даними асоціації World Steel, Україна стійко посідає другу сходинку. Обсяги виробництва коливаються від 12421 тис.тонн до 27579 тис.тонн. Як видно з рисунку 2 пік виробництва злитків в Україні приходиться на 2007 рік, а найменший обсяг виробництва на 2014 рік. 
Таблиця 1

Базисні темпи росту виробництва в Україні металургійної продукції за 2000-2014pр. (розраховано авторами за статистичними даними acoųiauiï World Steel) [5]

\begin{tabular}{|c|c|c|c|c|c|c|c|c|c|c|c|c|c|c|}
\hline Роки & $\begin{array}{l}2001 / \\
2000\end{array}$ & $\begin{array}{l}2002 / \\
2001\end{array}$ & $\begin{array}{l}2003 / \\
2002\end{array}$ & $\begin{array}{l}2004 / \\
2003\end{array}$ & $\begin{array}{l}2005 / \\
2004\end{array}$ & $\begin{array}{l}2006 / \\
2005\end{array}$ & $\begin{array}{l}2007 / \\
2006\end{array}$ & $\begin{array}{l}2008 / \\
2007\end{array}$ & $\begin{array}{l}2009 / \\
2008\end{array}$ & $\begin{array}{l}2010 / \\
2009\end{array}$ & $\begin{array}{l}2011 / \\
2010\end{array}$ & $\begin{array}{l}2012 / \\
2011\end{array}$ & $\begin{array}{l}2013 / \\
2012\end{array}$ & $\begin{array}{l}2014 / \\
2013\end{array}$ \\
\hline «Сира сталь» & 104,2 & 102,9 & 108,5 & 104,9 & 99,8 & 105,8 & 104,7 & 87,0 & 80,1 & 112,0 & 105,7 & 93,3 & 99,4 & 82,9 \\
\hline Стальні злитки & 104,1 & 83,4 & 91,9 & 104,9 & 99,7 & 127,8 & 103,5 & 81,1 & 69,1 & 99,2 & 105,7 & 93,3 & 103,6 & 79,3 \\
\hline $\begin{array}{l}\text { Гарячекатаний } \\
\text { прокат }\end{array}$ & 112,2 & 104,5 & 110,3 & 103,6 & 85,1 & 96,4 & 107,0 & 77,3 & 72,8 & 118,0 & 111,5 & 92,8 & 97,5 & 84,9 \\
\hline Труби та арматура & 95,9 & 90,6 & 142,6 & 98,4 & 112,7 & 114,3 & 99,3 & 90,9 & 66,1 & 117,2 & 125,5 & 94,7 & 78,9 & 79,9 \\
\hline Чавун & 102,6 & 104,8 & 106,9 & 105,2 & 99,1 & 107,0 & 108,2 & 86,9 & 82,9 & 106,5 & 105,6 & 98,7 & 102,1 & 85,2 \\
\hline
\end{tabular}

Таблиця 2

Ланцюгові темпи росту виробництва в Україні металургійної продукції за 2000-2014pр. (розраховано авторами за статистичними даними acoụiaųiï World Steel) [5]

\begin{tabular}{|c|c|c|c|c|c|c|c|c|c|c|c|c|c|c|}
\hline Роки & $\begin{array}{l}2001 / \\
2000\end{array}$ & $\begin{array}{l}2002 / \\
2000\end{array}$ & $\begin{array}{l}2003 / \\
2000\end{array}$ & $\begin{array}{l}2004 / \\
2000\end{array}$ & $\begin{array}{l}2005 / \\
2000\end{array}$ & $\begin{array}{l}2006 / \\
2000\end{array}$ & $\begin{array}{l}2007 / \\
2000\end{array}$ & $\begin{array}{l}2008 / \\
2000\end{array}$ & $\begin{array}{l}2009 / \\
2000\end{array}$ & $\begin{array}{l}2010 / \\
2000\end{array}$ & $\begin{array}{l}2011 / \\
2000\end{array}$ & $\begin{array}{l}2012 / \\
2000\end{array}$ & $\begin{array}{l}2013 / \\
2000\end{array}$ & $\begin{array}{l}2014 / \\
2000\end{array}$ \\
\hline «Сира сталь» & 104,2 & 107,2 & 116,3 & 121,9 & 121,6 & 128,7 & 134,8 & 117,4 & 94,0 & 105,2 & 111,2 & 103,8 & 103,2 & 85,5 \\
\hline Стальні злитки & 104,1 & 86,8 & 79,8 & 83,7 & 83,4 & 106,6 & 110,3 & 89,5 & 61,8 & 61,3 & 64,8 & 60,5 & 62,6 & 49,7 \\
\hline $\begin{array}{l}\text { Гарячекатаний } \\
\text { прокат }\end{array}$ & 112,2 & 117,2 & 129,3 & 133,9 & 114,0 & 109,9 & 117,6 & 90,9 & 66,1 & 78,1 & 87,1 & 80,8 & 78,8 & 66,8 \\
\hline Труби та арматура & 95,9 & 86,9 & 123,9 & 121,9 & 137,4 & 157,1 & 156,0 & 141,9 & 93,8 & 109,9 & 137,9 & 130,6 & 103,0 & 82,2 \\
\hline Чавун & 102,6 & 107,5 & 114,9 & 120,9 & 119,8 & 128,2 & 138,7 & 120,6 & 99,9 & 106,4 & 112,3 & 110,9 & 113,2 & 96,5 \\
\hline
\end{tabular}


Треба зазначити, що в останні п'ять років основним конкурентом вітчизняної металургії по виробництву злитків крім Російської Федерації, стає Індія. 3 2009 по 2012 рік, а також в 2014 році виробництво злитків Індією перевищує обсяги України. Як і 3 виробництвом «сирої» сталі, тенденція, що прослідковується за допомогою ланцюгових темпів, є негативною (табл.2.). У 2008 році в порівнянні з 2007 роком обсяги виробництва злитків, за даними асоціації World Steel, впали на 18,9\%, у 2009 році в порівнянні з 2008 році найбільший процент зниження виробництва - 30,9\%. Незначне падіння спостерігається у 2010 році в порівнянні з 2009 роком $-0,8 \%$ й у 2012 році в порівнянні з 2011 р. - 6,9\%. Але в 2014 році в порівнянні з 2013 роком зниження обсягів виробництва сягає $-20,7 \%$.

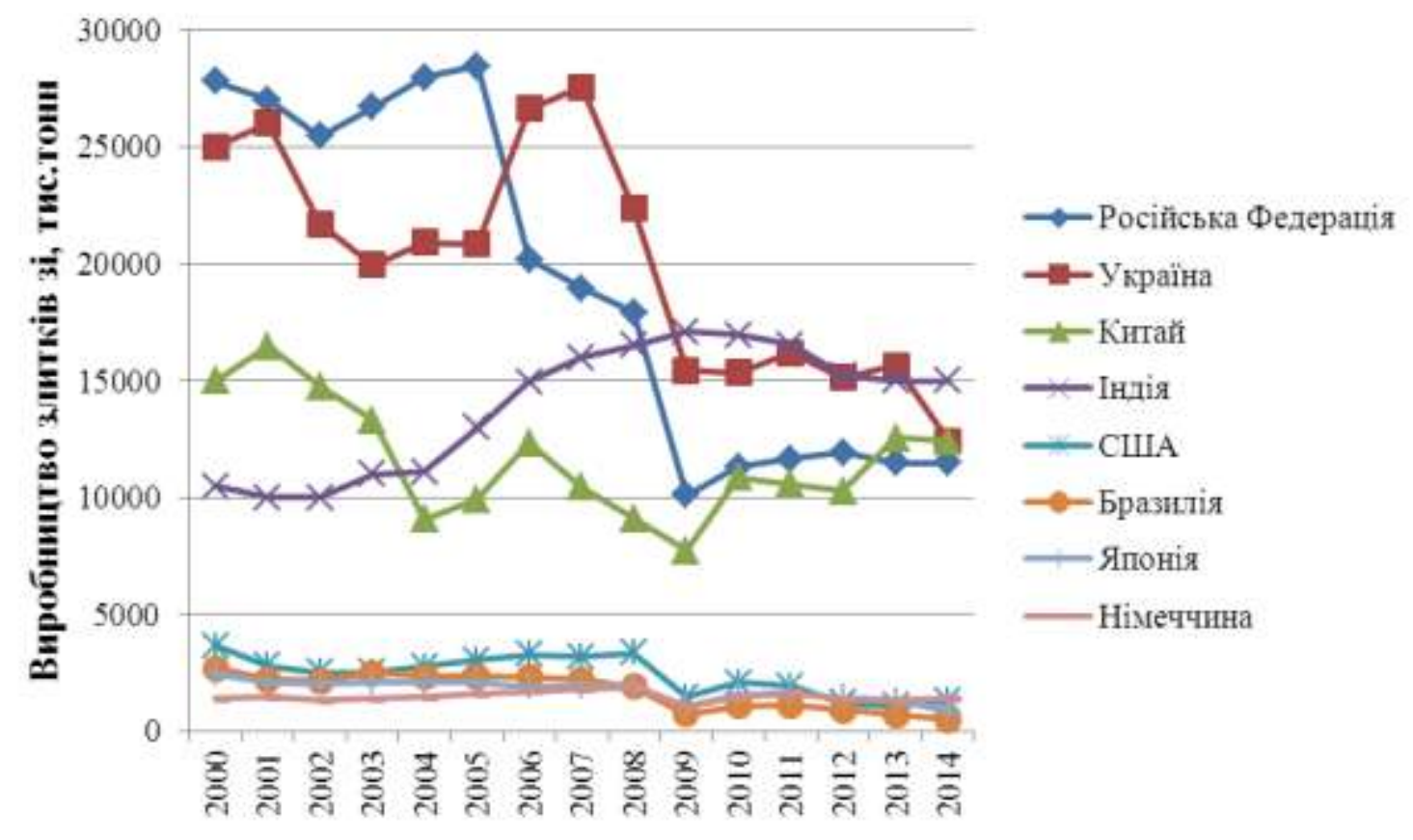

Рис.2. Діаграма виробництва злитків найбільшими країнами виробниками у 2000-2014 pр. (побудовано авторами за статистичними даними асоџіаџіï World Steel) [5]

Протягом 2000-2014pp. вітчизняна металургія також входила в першу десятку виробників гарячекатаного прокату. Обсяги його виробництва за статистикою асоціації World Steel коливались від 14900 тис.тонн (2009p.) до 30162 тис.тонн (2004p.). Основними конкурентами вітчизняним підприємствам за цим видом продукції виступають Італія, Тайвань та Бразилія (рис.3). Оцінка базисних темпів росту виробництва гарячекатаного прокату в порівнянні з 2000 роком свідчить про негативну тенденцію останні сім років (табл.1). При чому, найбільші рівень падіння виробництва спостерігається у2009 році - 33,9\% й у 2014 році - 33,2\%. За ланцюговими темпами також спостерігається зниження обсягів виробництва гарячекатаного прокату: найбільш суттєве падіння спостерігається у 2008 році в порівнянні з 2007 роком $22,7 \%$, у 2009 році в 


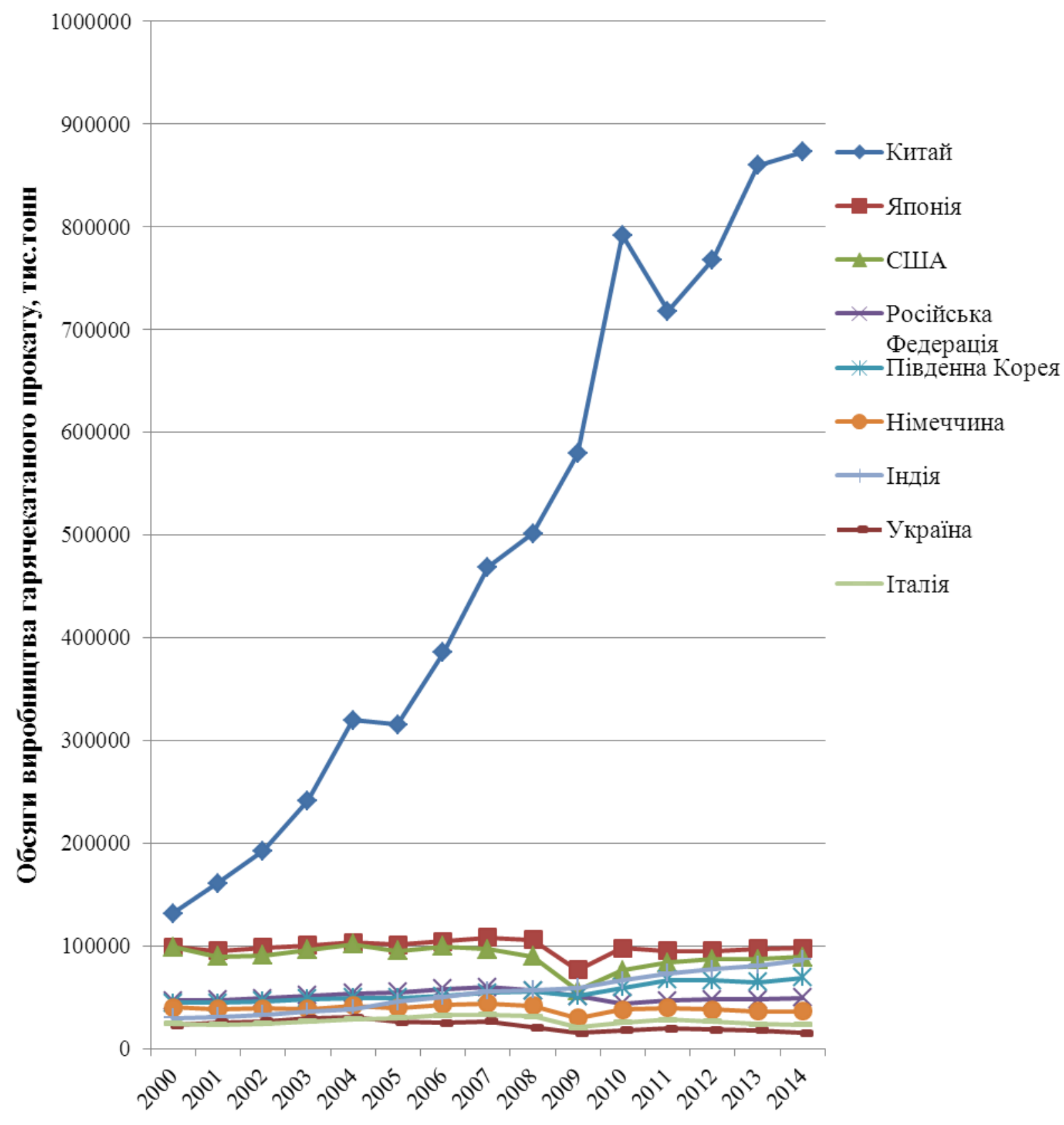

Рис.3. Діаграма виробництва гарячекатаного прокату найбільшими країнами виробниками у 2000-2014 рр. (побудовано авторами за статистичними даними асоиiачіï World Steel) [5]

порівнянні з 2008 р. - 27,2\%, а також у 2014 році в порівнянні з 2013 р. $15,1 \%$ (табл. 2 ).

Щодо наступного виду металургійної продукції: труба та арматури, за оцінкою статистичних даних асоціації World Steel Україна за обсягами значно відстає від основних виробників: Китаю, Російської Федерації, Японії. 


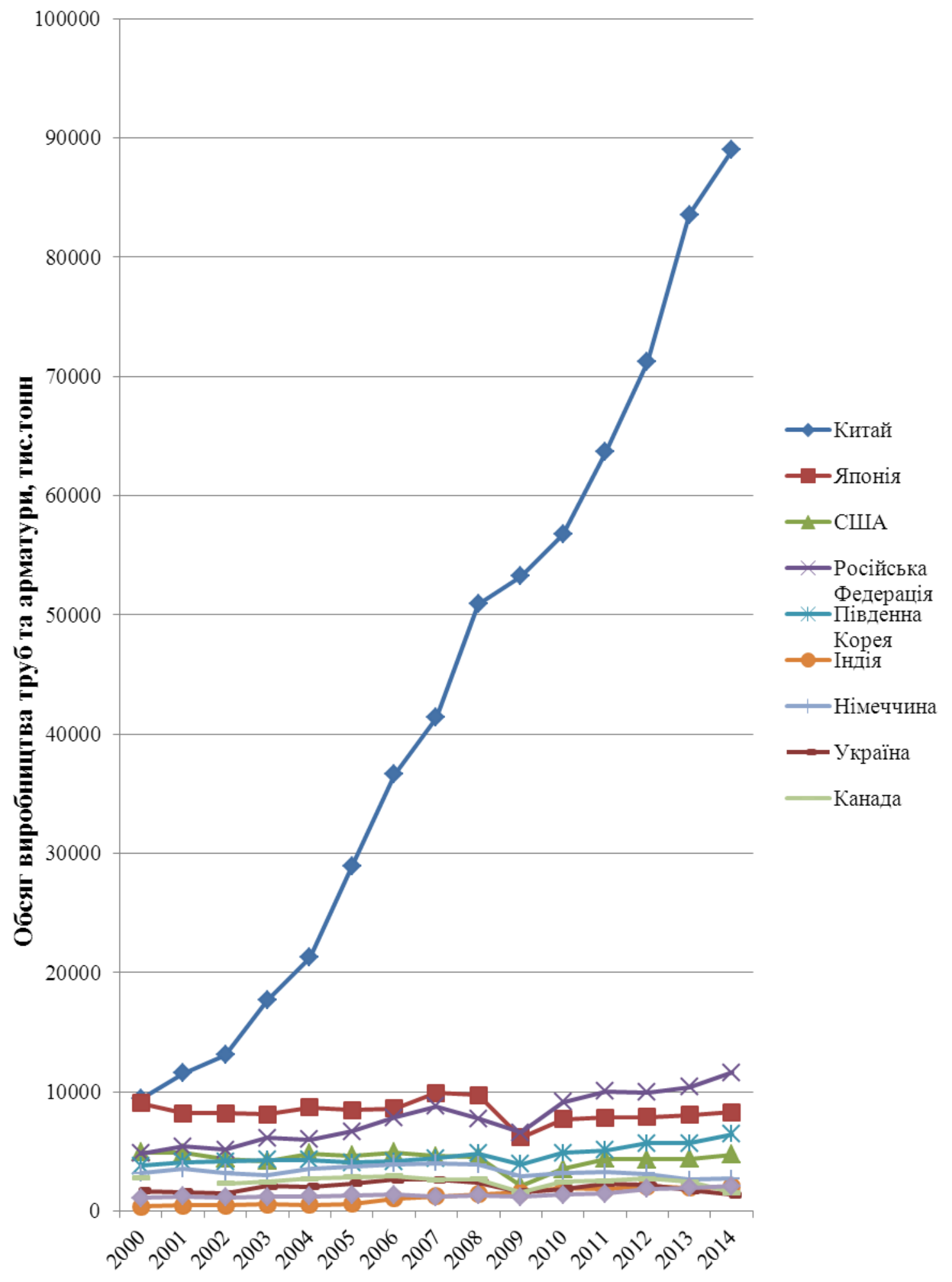

Рис. 4. Діаграма виробництва труб та арматури найбільшими країнами виробниками у 2000-2014 рр. (побудовано авторами за статистичними даними асоиіаміï World Steel) [5] 
Основними конкурентами вітчизняній металургії в даному сегменті в останні роки виступають не тільки Канада, а й Мексика та Індія (рис. 4). За статистичними даними World Steel обсяги виробництва труб та арматури в України коливаються від 1373 тис.тонн (2014 р.) до 2604 тис.тонн (2007 р.). Оцінка ланцюгових темпів виробництва свідчить про найбільше зниження у 2009 році в порівнянні з 2008 p. - 33,9\%, у 2013 році в порівнянні з 2012 роком - 21,1\%, й у 2014 році в порівнянні з 2013 р. - 20,1\% (табл.2).

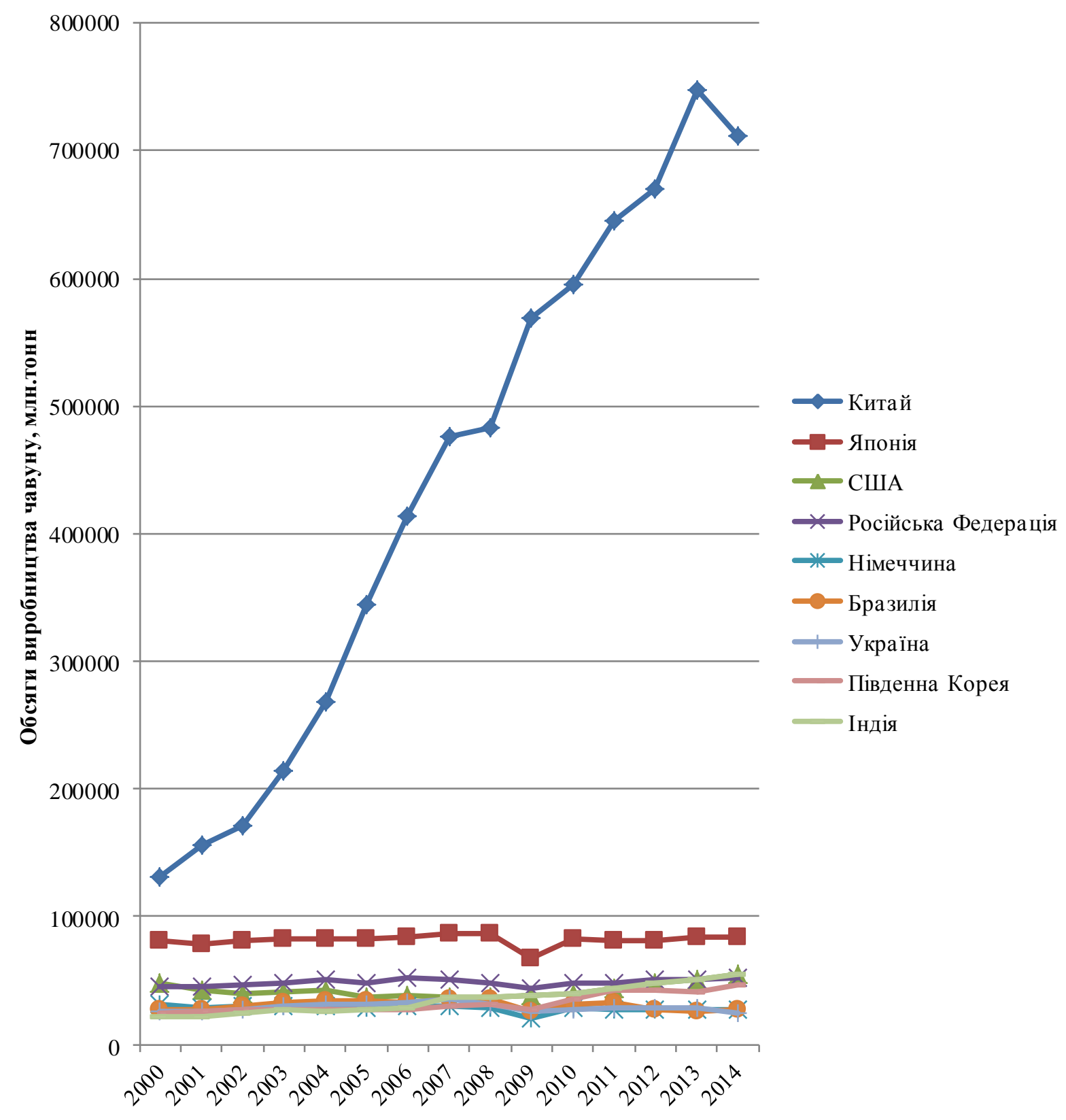

Рис. 4. Діаграма виробництва чавуну найбільшими країнами виробниками у 2000-2014 pр. (побудовано авторами за статистичними даними асочіащіï World Steel) [5] 
За базисними темпами зміни (табл.2.) нарощування обсягів виробництва труб та арматури спостерігається впродовж 2003-2008рp. та 2010-2013pp. У 2014 році в порівнянні з 2000 роком зниження обсягів виробництва дорівнює $17,8 \%$.

Треба зазначити, що по виробництву чавуну Україна відповідно даним асоціації World Steel, входить до найбільших дев'яти країн виробників. Протягом 2000-202pp. Україна за обсягами виробництва чавуну посідала 7 сходинку, з 2003 по 2005 роки - 6, в період 2006-2007pp. піднімається до п’ятої сходинки. 32008 року вітчизняних виробників починають випереджувати Південна Корея, Індія. У 2012-2013 роках Україна знову займає 7 місце за обсягами виробництва чавуну, але в 2014 році, як і по іншій продукції металургії ситуація значно погіршується. Оцінка базисних темпів росту свідчить, що найбільший приріст обсягів виробництва чавуну в порівнянні з 2000 роком спостерігається в 2007 році - 38,7\%, в 2004 р. 20,9\%, 2008 р. - 20,6\%. Щодо падіння обсягів виробництва, то в порівнянні 3 2000 роком, найбільше у 2014 році - 4,5\%. При розрахунку ланцюгових темпів зниження обсягів виробництва чавуну спостерігається у 2005 році в порівнянні з 2004 роком $(0,9 \%)$, у 2008 р. в порівнянні з 2007 р. $-13,1 \%$, у 2009 р. в порівнянні з 2008 р. - 17,1\%, у 2012 р. в порівнянні з 2011 р. - 1,3\%, у 2014 р. в порівнянні з 2013 р. $-14,8 \%$.

Проведений аналіз свідчить про складну ситуацію, що спостерігається в металургійній галузі України. Необхідність досягнення прийнятного рівня конкурентоспроможності на світовому ринку металургійних виробів викликає наростаючу потребу металургійних підприємств в підвищенні ефективності інноваційної діяльності.

Серед основних причин, що стримують розробку і впровадження інновацій в металургійній галузі, можна назвати: брак власних коштів, високу вартість нововведень, недостатню фінансову підтримку інноваційної діяльності з боку держави, високий рівень економічних ризиків, тривалі терміни окупності нововведень.

Щодо наявності перспективних напрямків розвитку металургійної галузі, то вітчизняні вчені називають: впровадження у доменному виробництві установок вдування пиловугільного палива (ПВП); диверсифікацію металургійного виробництва, а саме освоєння випуску нових, високотехнологічних видів продукції: прокату 3 покриттям, у тому числі холодної прокатки, виробів з легованої сталі, продуктів прямого відновлення залізних руд, каліброваного прокату, гнутих профілів та ін. [1;2; 3; 4].

Висновки. Таким чином, оцінка статистичних даних асоціації World Steel дозволяє стверджувати, що з одного боку, вітчизняна металургія відіграє значну роль в світовому металургійному виробництві, з іншого, що в останні роки Україна стала здавати свої позиції. По окремим позиціям металургійної 
продукції вітчизняних виробників обігнали такі країни, як Індія, Туреччина, Бразилія. Відсутність розробки та впровадження передових технологій в умовах несприятливої ринкової кон'юнктури може мати негативні наслідки для вітчизняної металургії, аж до проблеми iï виживання. У зв'язку з цим особливої актуальності набуває необхідність розробки та реалізації стратегій розвитку металургійних підприємств, в основі яких повинен лежати об'єктивний аналіз інноваційного рівня виробництва в металургії України, як складовій частині світового виробництва металопродукції.

Наукової новизною дослідження $є$ науково-методичний підхід до аналізування виробничо-комерційної діяльності промислових підприємств (на прикладі металургійних), який надає можливість визначати тенденції розвитку та місце на міжнародному ринку промислової продукції відповідно до профіля підприємства.

Перспективами подальших досліджень за даної темою $є$ розробка методичних підходів оцінки спроможності металургійних підприємств до реалізації інноваційних стратегій розвитку.

\section{Література:}

1. Большаков В. І. Чорна металургія і національна безпека України / В. І. Большаков, Л. Г. Тубольцев // Вісник НАН України. - 2014. - № 9. - С. 48-58.

2. Плавшуда К. В. Державне програмування розвитку металургійного комплексу України / К. В. Плакшуда // Вісник національного університету «Юридична академія України імені Ярослава Мудрого». - 2013. - №2 (13). - С. 211-219.

3. Резнікова О. С. Перспективи розвитку металургійних підприємств України в умовах глобальної конкуренції / О. С. Резнікова // Інтелект XXI. - 2014. - № 3. - С. 54-63.

4. Украинская металлургия: современные вызовы и перспективы развития: моногр. / А. И. Амоша, В. И. Большаков, А. А. Минаев, Ю. С. Залознова, Л. А. Збаразская, Ю. В. Макогон и др.; НАН Украины, Ин-т экономики пром-сти. - Донецк, 2013. - 114 с.

5. Worldsteel Association [Електронний peсурс]. - Режим доступу : http://www.worldsteel.org 